\title{
A REVIEW OF THE EXISTING HYPOTHESES ON THE ORIGIN OF THE SECONDARY SILICATE ZONES AT THE CONTACTS OF INTRU- SIVES WITH LIMESTONES.
}

\author{
By W. L. UGLow. \\ INTRODUCTION.
}

During the last ten years, the number of ore deposits which have been found at the contacts of intrusive igneous rocks with limestones has rapidly increased. This has been in part the result of the clearer understanding and the easier recognition of this type of deposits which the study of contact metamorphism and ore deposition has brought about. The investigation of the increasing number of deposits has naturally led to a discussion as to the exact manner in which such bodies of ore have originated. A number of different hypotheses have been advocated for the formation both of the ores and the contact metamorphic minerals which have been developed by the intrusive igneous rocks in limestones. There has been not a little controversy between those who advocate the different methods of genesis. As all geologists and mining engineers may not be entirely familiar with the arguments which have been presented by those who favor one or the other of the proposed hypotheses, and because more attention has been given to the origin of the associated ores than to the study of the very extensive portions of the contact. zones where little or no ore has been found, the writer feels that the following critical review of the existing theories is warranted.

Inasmuch as the ores which are associated with these contact zones occupy but a small portion of the contact area, more attention will be given to the non-metalliferous portion than to that which is composed chiefly of ore bodies. The sources of information are the various published reports which have been written on those districts which are of economic importance, as 
they constitute the major portion of the available literature on the subject. Those facts which seem to have general significance have been tabulated in the following pages, and it is hoped that the reader may obtain from these tables a clearer idea as to the relative amount of accurate observation which supports either one or the other of the two most important hypotheses. It is the writer's intention to follow this review of the literature by a paper based upon extensive field observation.

\section{GENERAL CHARACTERISTICS OF LIMESTONE CONTACTS.}

Distribution.-Contacts of limestones with intrusive igneous rocks occur in greatest number in the western part of the continent of North America. They are here developed along the borders of extensive batholiths of igneous rock which have invaded sedimentary series and which have been revealed at the surface by the erosion of the overlying covers. In the eastern part of the continent they are less abundant. Some important ones occur, however, in the Adirondacks, the highlands of New Jersey, and the Piedmont district. The metamorphosed sedimentary rocks here are mostly Algonkian or Paleozoic. The sediments in these eastern occurrences have probably been subjected to repeated dynamic metamorphism, so that all, or nearly all, evidence of early contact action has been completely obliterated. In the western occurrences, on the other hand, the invaded rocks are frequently of late Paleozoic or early Metazoic age, and the contact zones, except for weathering, remain today in practically their original condition. They furnish, therefore, excellent opportunities for critical study.

Invaded Rocks.-The sedimentary rocks into which the intrusives have made their way are not exclusively limestones. Shales, sandstones, and conglomerates are of frequent occurrence. There are, of course, gradations between all of these different types. Limestones frequently contain sand or clay; sandstones, lime, clay, or iron; while the shales may contain lime or sand. In nearly all of the western occurrences a variety of sedimentary rocks are present, and all of the main types of sediments with 
the intermediate gradations are more or less extensively represented. Upon all of these sediments the intrusives have exerted contact effect, but the ore bodies which are occasionally found along the igneous contacts are most commonly developed in the limestone.

Associated Ores.-Many of the ore deposits which are developed along these limestone contacts are sufficiently extensive and of sufficient value to be of considerable commercial importance. This is particularly true in the case of iron and copper. Iron is found in such association as magnetite ${ }^{1}$ and specularite $;{ }^{1}$ copper occurs very frequently as chalcopyrite and bronite, tetrahedrite and cupriferous pyrites; $;$ lead and zinc are occasionally found as galena and sphalerite $;^{3}$ native gold occurs in wollastonite at Chiapas, Mexico, ${ }^{4}$ and in arsenopyrite on the Simillkameen River, B. C. $;^{5}$ platinum is found in wollastonite ${ }^{6}$ bismuth occurs as tetradymite and bismuthinite $;^{7}$ and silver ${ }^{8}$ as argentite, associated usually with the copper deposits. Of the above-named metal-bearing minerals, iron and copper alone occur in bodies of sufficient size and value to be of commercial importance. In number and extent the iron deposits overshadow the copper, and it is only necessary to mention, in the case of copper, the camps at Clifton-Morenci, etc. Gold, silver, lead, and zinc are occasionally recovered as by-products.

${ }^{1}$ C. K. Leith and E. C. Harder, "The Iron Ores of the Iron Springs District, Utah," U. S. G. S., Bull. 338, I908.

${ }^{2}$ E. C. Harder, "Iron Ores of Western and Central California," U. S. G. S., Bull. 430 ; F. L. Ransome, U. S. G. S., Prof. Paper 2I (Bisbee) ; W. Lindgren, U. S. G. S., Prof. Paper 43 (Clifton-Morenci).

${ }^{3}$ W. O. Crosby, "The Limestone-Granite Contact-Deposits of Washington Camp, Arizona," Trans. A. I. M. E., XXXVI., 1905, p. 626.

"E. T. McCarty, "Mining in the Wollastonite Ore-Deposits of the Santa Fe Mine, Chiapas, Mexico," Trans. Inst. Min. and Met., Vol. IV., I896, pp. I69-I89.

"W. H. Weed, “Ore Deposits near Igneous Contacts," Trans. A. I. M. E., XXXIII., I903, p. 734.

'L. Hundeshagen, "The Occurrence of Platinum in Wollastonite on the Island of Sumatra," Trans. Inst. Min. and Met., July 21, I904.

"W. H. Weed, "Ore Deposits near Igneous Contacts," Trans. A. I. M. E., XXXIII., 1903, p. 733.

'W. Lindgren, “Copper Deposits of the Seven Devils, Idaho," U. S. G. S., 2oth Ann. Rept., Part III., p. 249; E. T. McCarty, op. cit. 
Contact Metamorphic Minerals.-Associated with the metallic minerals are gangues of lime silicates and other contact metamorphic minerals, which show no marked variation whether iron or copper minerals preponderate in the ore.

Below is a list of the common "contact-metamorphic" minerals. They have been arranged in two distinct groups. Group 2 includes those minerals which contain elements such as boron, fluorine, chlorine or for other reasons later discussed may be admittedly the products of igneous emanation; group I contains the disputed series of what will be here termed the "silicate zone" group. It is mainly about this group that discussion has arisen.

GROUP I.

Grossularite ( $\mathrm{Ca}, \mathrm{Al}, \mathrm{SiO}_{2}$ ).

Andradite ( $\left.\mathrm{Ca}, \mathrm{Fe}, \mathrm{SiO}_{2}\right)$.

Epidote ( $\mathrm{Ca}, \mathrm{Al}, \mathrm{Fe}, \mathrm{SiO}_{2}, \mathrm{H}_{2} \mathrm{O}$ ).

Diopside ( $\mathrm{Ca}, \mathrm{Mg}, \mathrm{SiO}_{2}$ ).

Tremolite ( $\mathrm{Ca}, \mathrm{Mg}, \mathrm{SiO}_{2}$ ).

Actinolite ( $\mathrm{Ca}, \mathrm{Mg}, \mathrm{Fe}, \mathrm{SiO}_{2}$ ).

Wollastonite $\left(\mathrm{Ca}, \mathrm{SiO}_{2}\right)$.

Biotite ( $\left.\mathrm{Mg}, \mathrm{Fe}, \mathrm{Al}, \mathrm{SiO}_{2}, \mathrm{H}_{2} \mathrm{O}\right)$.

Calcite $\left(\mathrm{CaCO}_{3}\right)$.

Quartz $\left(\mathrm{SiO}_{2}\right)$.
GROUP 2.

Scapolite ( $\mathrm{Ca}, \mathrm{NaCl}, \mathrm{Al}, \mathrm{SiO}_{2}$ ).

Vesuvianite (Ca, Al, F, $\mathrm{SiO}_{2}, \mathrm{OH}$ ).

Quartz $\left(\mathrm{SiO}_{2}\right)$.

Muscovite (H, K, Al, $\left.\mathrm{SiO}_{2}\right)$.

Albite $\left(\mathrm{Na}, \mathrm{Al}, \mathrm{SiO}_{2}\right)$.

Axinite ( $\mathrm{Ca}, \mathrm{Al}, \mathrm{Fe}, \mathrm{Mn}, \mathrm{B}, \mathrm{SiO}_{2}$ ). Apatite ( $\mathrm{Ca}, \mathrm{F}, \mathrm{Cl}, \mathrm{P}_{2} \mathrm{O}_{5}$ ).

Tourmaline ( $\mathrm{Fe}, \mathrm{Mg}, \mathrm{B}, \mathrm{Al}, \mathrm{SiO}_{2}$ ). Fluorite $\left(\mathrm{CaF}_{2}\right)$.

RELATIVE SUCCESSION OF THE TWO GROUPS.

Although the ore minerals are generally intergrown with the secondary silicates there is much which indicates a difference in the time of formation of the metalliferous and gangue minerals. Metallographic methods have been used on specimens, and in many cases a definite order of crystallization has been determined. Kemp has shown that at San Jose, Mexico, ${ }^{1}$ and at White Knob, Idaho, ${ }^{2}$ the ore-minerals were formed later than the silicates, and often cut through them as veinlets. Leith and

${ }^{1}$ J. F. Kemp, “The Copper Deposits of San Jose, Tamaulipas, Mexico," Trans. A. I. M. E., XXXVI., 1906, pp. 178-203.

${ }^{2}$ J. F. Kemp and C. G. Gunther, "The White Knob Copper Deposits, Mackay, Idaho," Trans. A. I. M. E., XXXVIII., I907, pp. 269-293. 
Harder, in their Iron Springs bulletin, ${ }^{\mathbf{1}}$ establish a succession of: first, silicate minerals and second, ore-minerals. Barrel1 ${ }^{2}$ draws attention to the same feature at Marysville, Montana. Stutzer ${ }^{3}$ determined the following order at the White Horse Pass mines in the Yukon: $(a)$ pyroxene, and rarely magnetite, $(b)$ magnetite, $(c)$ garnet with a few metallic sulphides, $(d)$ amphibole and the greater part of the sulphides, $(e)$ calcite. At Morenci, Arizona, Lindgren ${ }^{4}$ records the simultaneous crystallization of the lime-silicates and magnetite, together with some of the sulphides, while a great part of the sulphides are plainly of later formation, and cut the earlier minerals in veinlets and stringers. Spurr and Garrey ${ }^{5}$ reach a similar conclusion in their observations upon the garnet-zones of Velardeña, Mexico; and Ransome ${ }^{6}$ in his new professional paper on the Breckenridge District, Colorado, concedes a dual stage.

HYPOTHESES OF ORIGIN.

The chief point on which geologists differ is as to the mode of origin of both the silicate and ore-minerals. The main views may be given in brief :

I. All the minerals of the contact-zone are the result of recrystallization of substances present before the limestone was metamorphosed. Ore-minerals and silicate-minerals are of the same origin. No introduction of material from the intrusive has occurred. This is the hypothesis which Rosenbusch, ${ }^{7} \mathrm{Zirkel}^{8}$

${ }^{1}$ C. K. Leith and E. C. Harder, "The Iron Ores of the Iron Springs District, Utah,” U. S. G. S., Bull. 338, 1908.

${ }^{2}$ J. Barrell, "Geology of the Marysville Mining District, Montana," U. S. G. S., Prof. Paper 57.

${ }^{3}$ O. Stutzer, "Die Kontaktmetamorphen Kupfererzlagerstaeten von White Horse, Yukon," Zeitschr. für prakt. Geol., March, I909, p. I20.

"W. Lindgren, "The Copper Deposits of the Clifton-Morenci District," U. S. G. S., Prof. Paper 43, I905.

'J. E. Spurr and G. H. Garrey, "The Copper Deposits of the Velardeña District, Durango, Mexico," Econ. Geol., Vol. III., p. 688.

${ }^{\circ}$ F. L. Ransome, "Geology and Ore Deposits of the Breckenridge District, Colorado," U. S. G. S., Prof. Paper 75, I9II.

${ }^{7}$ Rosenbusch, "Mikroskopische Physiographie," 3d ed., p. 85.

${ }^{8}$ Zirkel, "Lehrbuch der Petrographie," 2d ed., Vol. I., pp. 587-588. 
and Brögger advocate and may be entitled the old or original hypothesis.

2. A commonly accepted view at the present time is that of which J. F. Kemp ${ }^{1}$ seems to be the chief supporter. . It is almost diametrically opposed to that of Rosenbusch, Zirkel and Brögger. According to Kemp, the limestone furnishes only lime and some carbon dioxide to the minerals of the contact-zone. He maintains that the intrusive on cooling emits great quantities of vapors containing $\mathrm{SiO}_{2}, \mathrm{Al}_{2} \mathrm{O}_{3}, \mathrm{Fe}_{2} \mathrm{O}_{3} \mathrm{FeO}, \mathrm{MgO}, \mathrm{H}_{2} \mathrm{O}$, as well as metallic sulphides and oxides. The silica, alumina, and iron oxides unite with the lime of the limestone to form lime silicates. Of course, if the original limestone should contain silica, alumina, or iron oxide as impurities, they might well be used in the formation of the secondlary minerals.

3. There are other views which seem more reasonable in that they take a sort of intermediate position with regard to the above-mentioned two:

(A) J. Barrell:2 A period of metamorphism follows the intrusion, during which gases are expelled from the sediments, the volume contracts, and there is a general recrystallization. Subsequent to this comes a period of metasomatism, during which a replacement of the metamorphosed sediments takes place, the replacing material coming as eruptive afteractions from the intrusive. According to this view, the silica and alumina existing in carbonate rocks combine with the bases and set free a proportionate amount of carbon dioxide. The absolute amount of lime and magnesia is the same after the process is completed as before. The emanations, which proceed from the magma, during the metasomatic phase of the contact action, consist chiefly of silica, iron oxide, water, sulphur, besides, of course, other oreproducing compounds.

${ }^{1}$ J. K. Kemp, "Contact Deposits: Types of Ore Deposits," Mining and Scientific Press, I9II.

'J. Barrell, "Geology of the Marysville Mining District, Montana," U. S. G. S., Prof. Paper 57; "Physical Effects of Contact Metamorphism," Am. Jour. Sc., 1902, pp. 279-296. 
(B) A. C. Lawson : ${ }^{1}$ The heated intrusive disturbs the groundwater circulation, and gives it new impetus to work over the rocks of the vicinity. This increased activity of the ground-water is responsible, then, for the formation of both the secondary silicates and the ores. In this way, Lawson avoids the necessity of looking for a contribution from the magma. In his own words : "The circulation would always be upward on the periphery of the hot mass. . . . Such a circulation of the heated ground-water would be quite competent to do all that is ascribed to magmatic waters, including the formation of lime-silicate zones."

$(C)$ W. Lindgren : ${ }^{2}$ There is a combination of a recrystallization of impurities with an introduction of large amounts of $\mathrm{SiO}_{2}$ and $\mathrm{Fe}_{2} \mathrm{O}_{3}$, and small amounts of $\mathrm{Al}_{2} \mathrm{O}_{3}$, to form the secondary silicates. The ore-minerals are partly formed at the same time as the silicates, and are partly the result of a working.over of the intrusives by hot waters. In his earlier work, ${ }^{3}$ he states that the "metallic-minerals are intergrown with the various gangue minerals,- -garnet, epidote, wollastonite, etc.-in such a manner that they must be considered as having a simultaneous origin. The theory of a subsequent introduction of the metallic ores is decidedly untenable." More recently, however, he has come to recognize more or less definitely a sort of dual stage in the formation of the contact-zones.

$(D)$ C. K. Leith: ${ }^{4}$ According to the hypothesis set forth by Leith and Harder in their Iron Springs bulletin, the secondary silicate zone is largely a recrystallization of constituents already in the limestone, combined with an expulsion of the excess calcium carbonate. This view does not by any means involve a total absence of infiltrated material from the intrusive, but its advocates maintain that the so-called contact-zone can be litholog-

${ }^{1}$ A. C. Lawson, "Types of Ore Deposits-A Review," Min. and Sc. Press, Feb. 3, I9I2, p. 200.

"W. Lindgren, "Copper Deposits of the Clifton-Morenci District, Arizona," U. S. G. S., Prof. Paper 43, 1905.

"W. Lindgren, "The Character and Genesis of Certain Contact-Deposits: Genesis of Ore-Deposits," I90I, p. 726.

"C. K. Leith and E. C. Harder, "The Iron Ores of the Iron Springs District, Utah,” U. S. G. S., Bull. 338, 1908. 
ically divided into two parts, one part of which is formed entirely by recrystallization in the early stages of the metamorphism, and the other part by later addition of material in the way of emanations from the magma. The minerals which belong to the first class are those mentioned in the left-hand columns on pages 7 and 8, while those of the second class include among others those listed in the right-hand column on the same pages, together with the metallic minerals. It will be noticed that the non-metallic minerals of the latter class nearly all contain an element more or less foreign to sedimentary series, e. g., bonon, fluorine, chlorine, beryllium, etc. These are typically found in magmatic emanations. The metallic minerals may be either direct contributions from the magma, or hot water deposits resulting from the working over of the hot intrusives. Definite evidence is obtained in the area described of the earlier formation of the first class of minerals. The two periods no doubt overlapped, but there is a somewhat well-marked distinction in the matter of time.

The magnitude of the iron deposits of the West, especially as they occur in connection with acidic intrusives, makes it almost impossible to suppose that they have been formed in any other way than by direct introduction from the cooling magma. ${ }^{1}$ The copper deposits, on the other hand, are low grade and are disseminated. The igneous rocks with which they are associated show the results of leaching by hydrothermal action, and also contain traces of copper. There seems to be no reason why the copper could not have been at least partially contributed by the hot waters that leached the intrusives. ${ }^{2}$

The last hypothesis seems to the writer to be the most probable. In the present paper, an attempt is made to collect and correlate facts that will tend to substantiate this hypothesis. During the discussion, the application of the expressions "secondary silicate zone," "contact-zone," etc., will be limited to that phase characterized by the presence of the minerals of the first class, as

${ }^{1}$ Personal communication.

${ }^{2}$ Personal communication. 
mentioned above. It is freely admitted that minerals containing such elements as boron, fluorine, beryllium, etc., required for their formation a contribution from igneous sources.

TABLE OF COMPARATIVE EVIDENCE.

Setting aside the question of how and when the ore-minerals of the contact-zones were formed, the problem resolves itself into the following alternative: (a) Is the "secondary silicate zone" the result of a combination of the lime of the limestone with other oxides furnished directly by the intrusive, or $(b)$ is it entirely the result of a redistribution and recrystallization of the impurities already in the limestone, without any contribution from the magma?

The evidence obtainable from published articles which deal with this question has been arranged in two columns in the following tabulated summary. Arguments from each individual publication are presented together, on one side or other of the center line according to the view to which they lend support. Facts which equally favor or oppose both hypotheses are not noted in the compilation. Letters and figures appended to the various paragraphs thus: ( $A$, pp. 199-200) refer to the list of references on page 45 of this paper. 


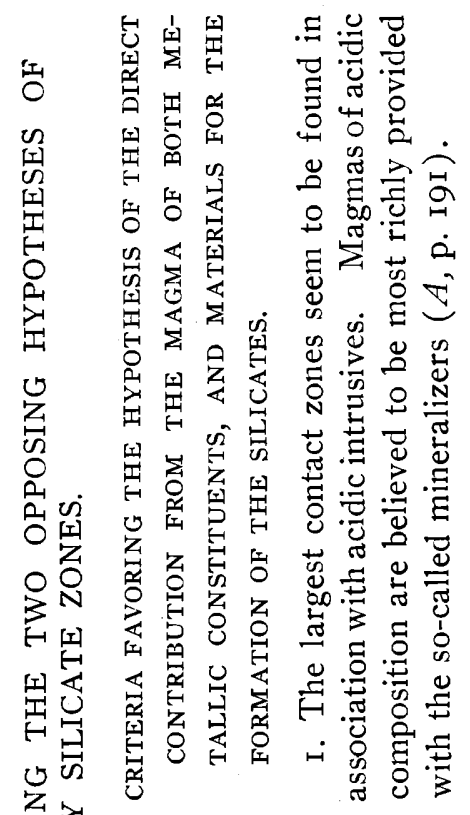

芯品

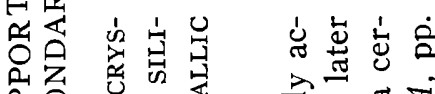

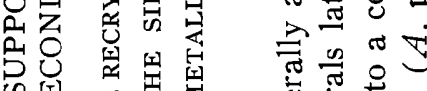

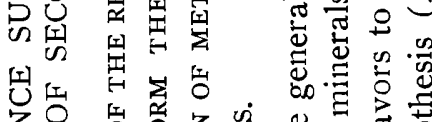

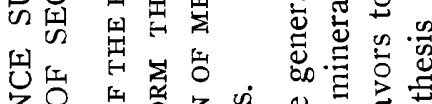

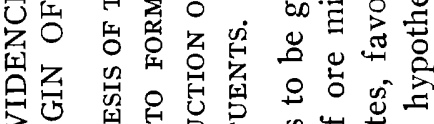

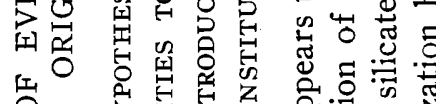

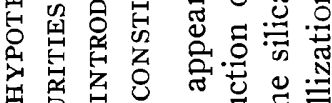

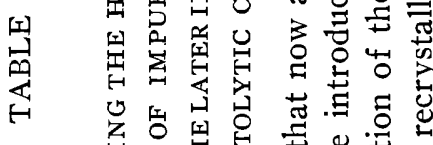

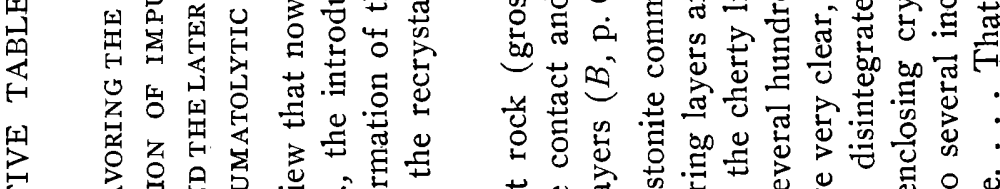

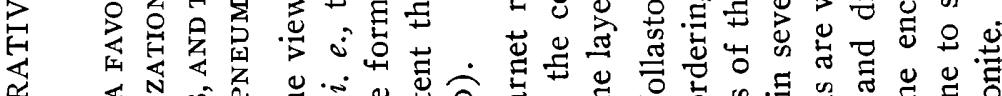

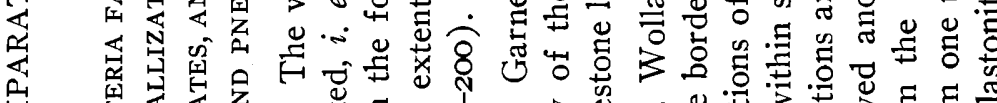

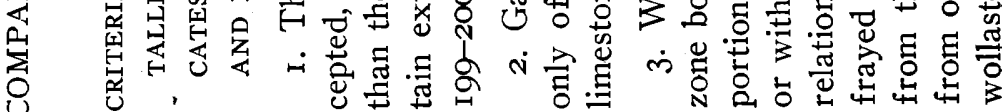


范

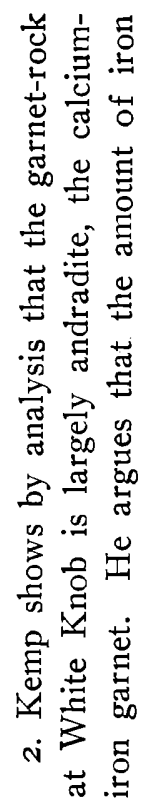

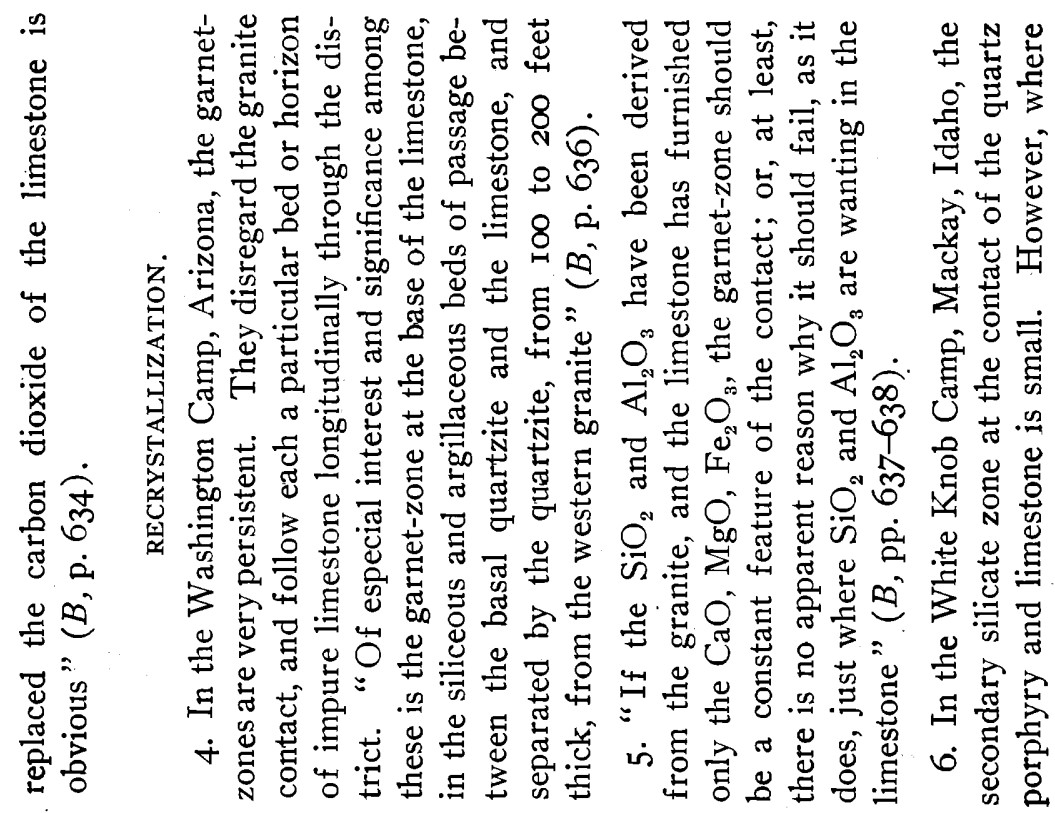




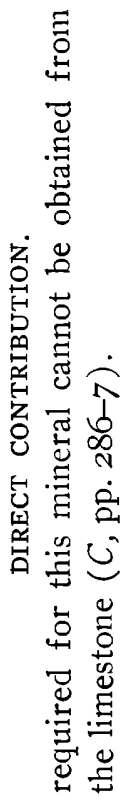

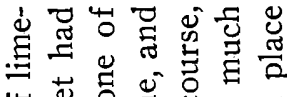
㟧

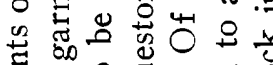

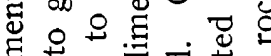

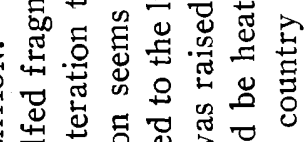

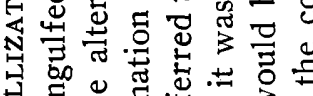

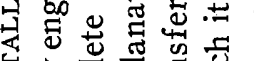

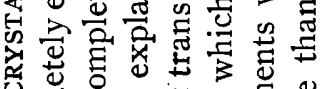

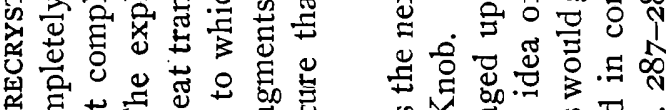

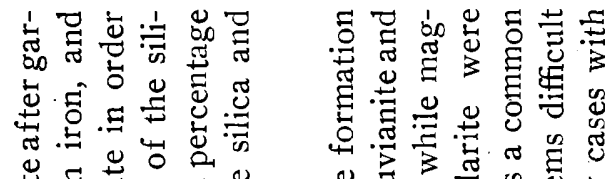

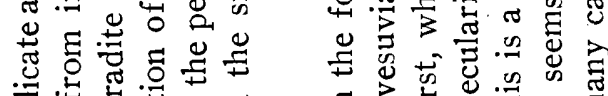

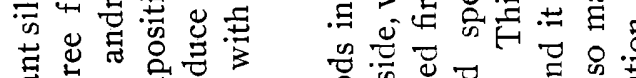

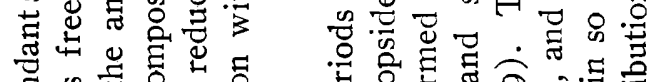

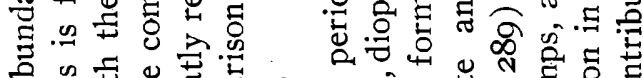

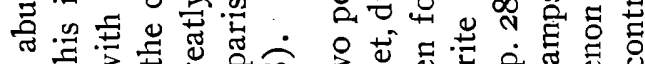

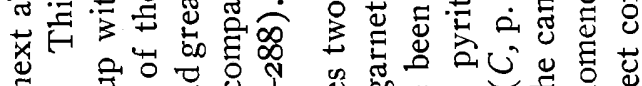

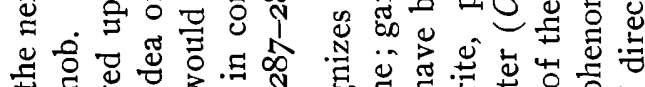

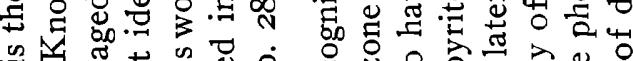

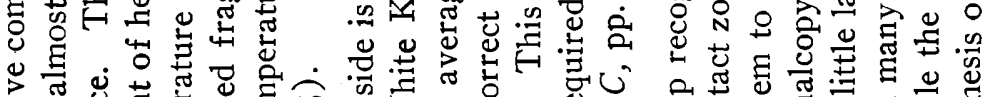
.

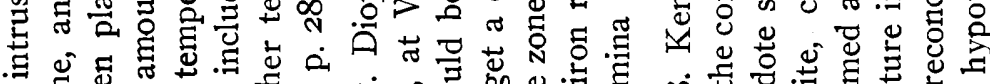

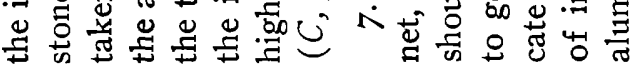


总

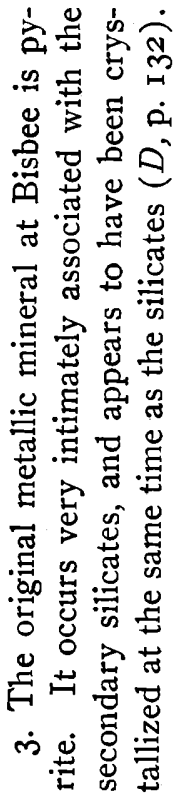

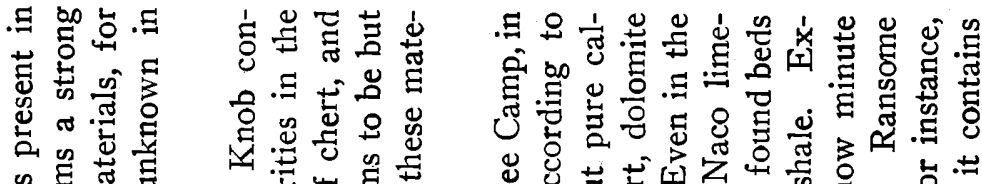

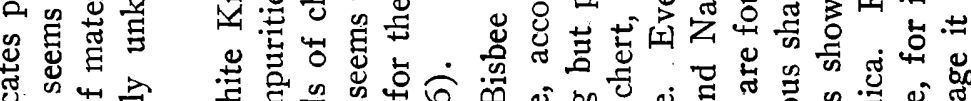

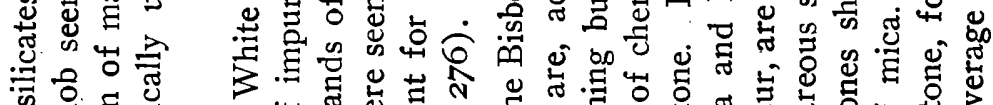

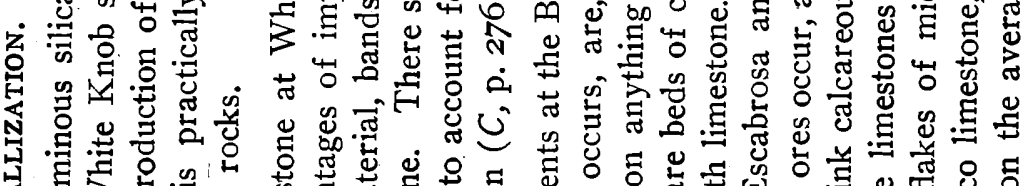

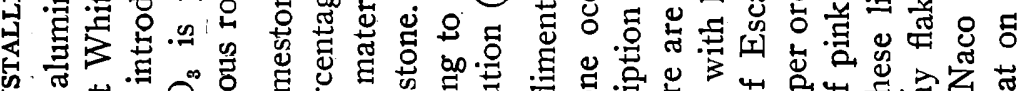
点离.

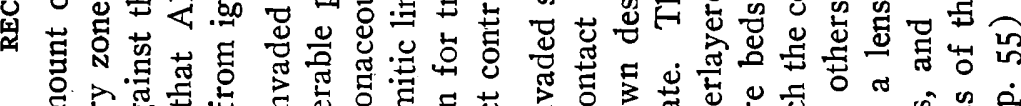

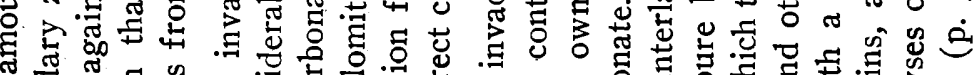

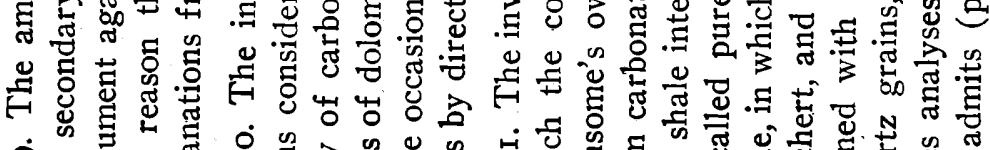
○े

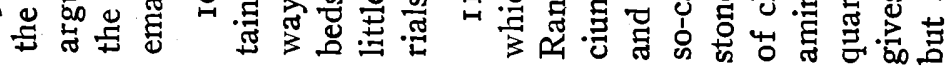


突

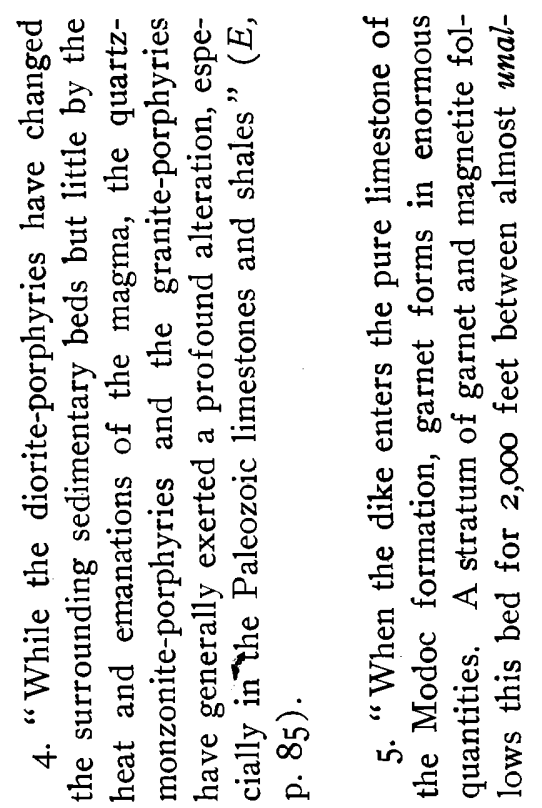

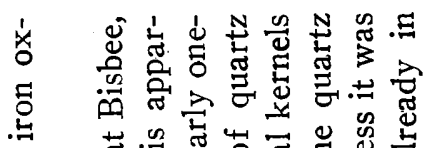

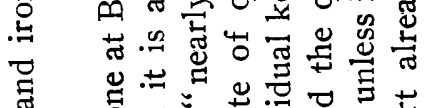

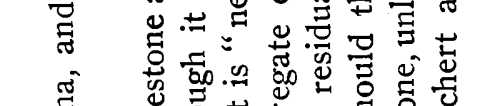

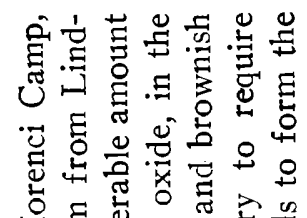

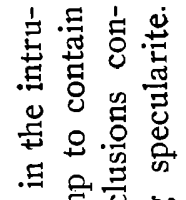

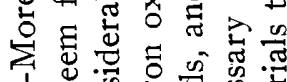

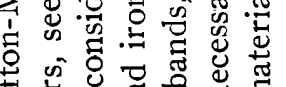

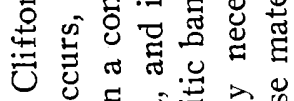

U

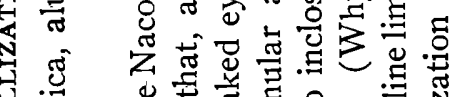

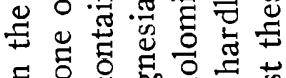

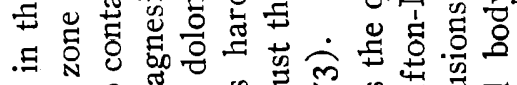

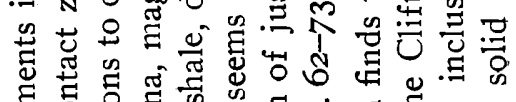

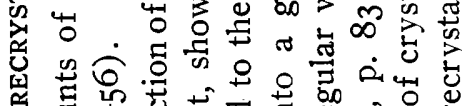

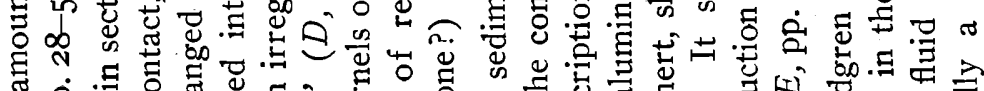

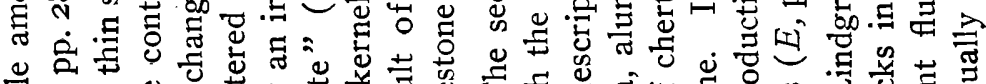

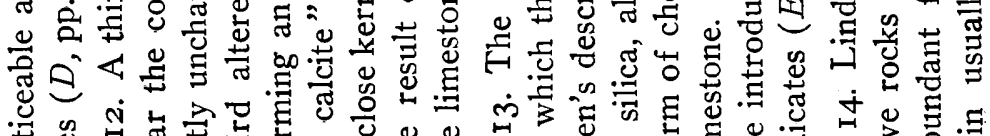

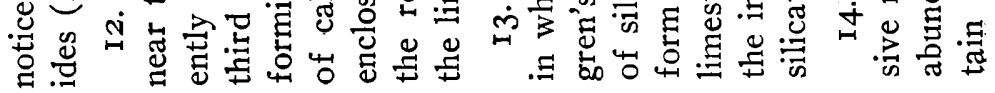




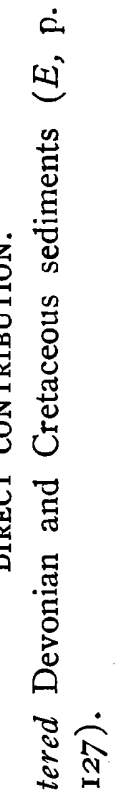

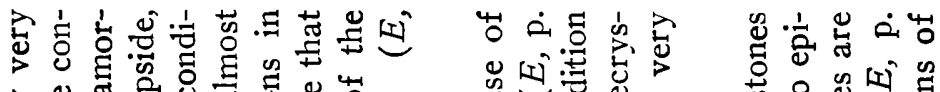

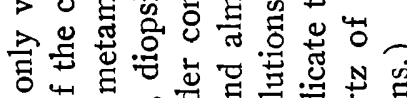

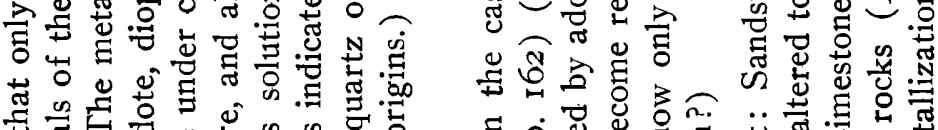

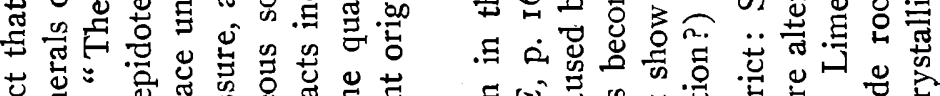

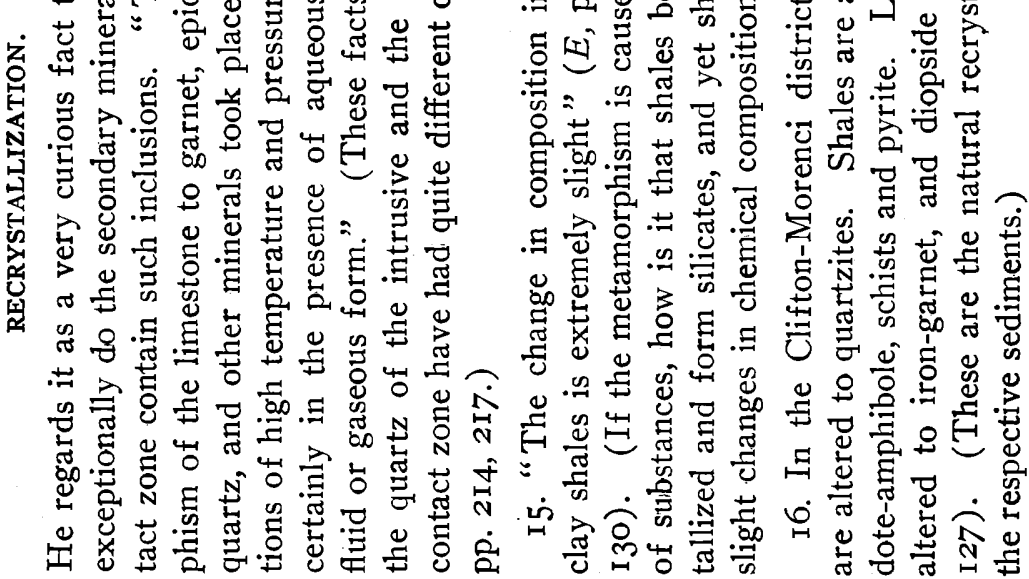




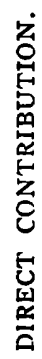

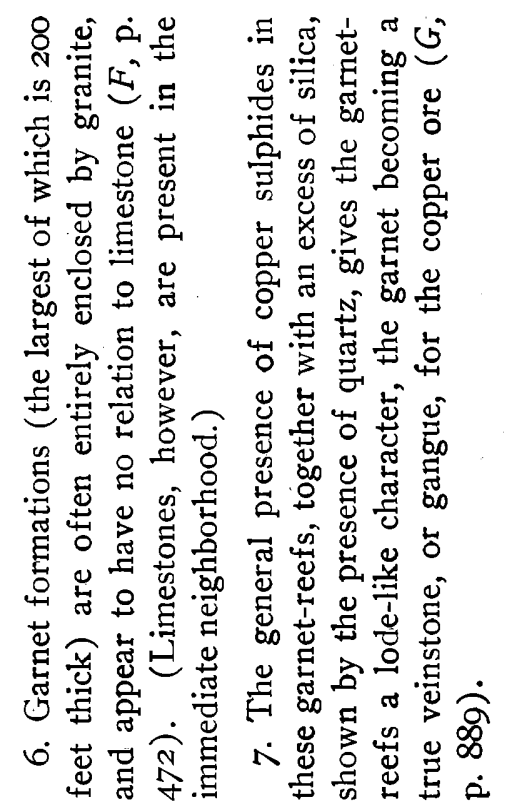

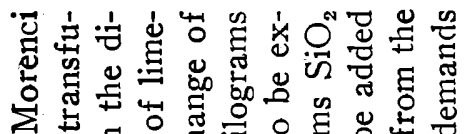

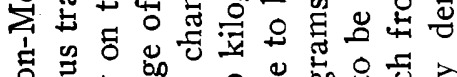

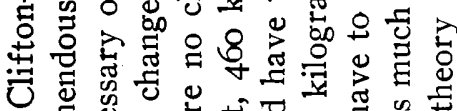

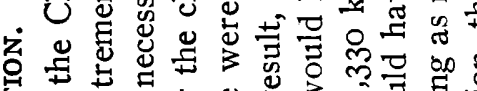

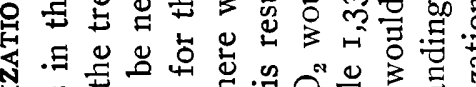

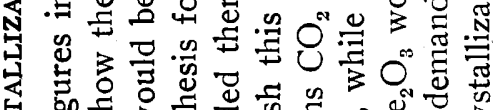

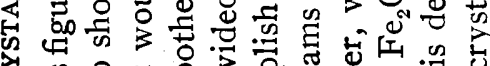

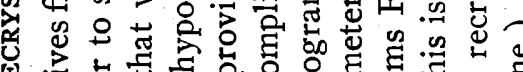

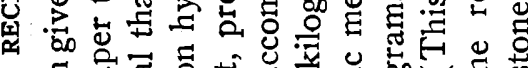

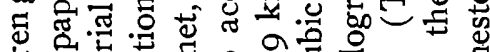

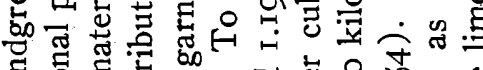

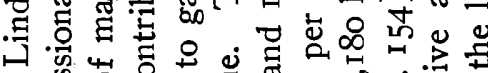

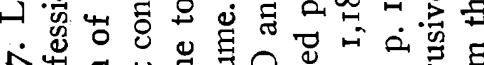
人出

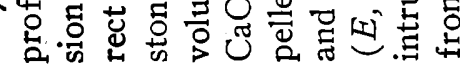



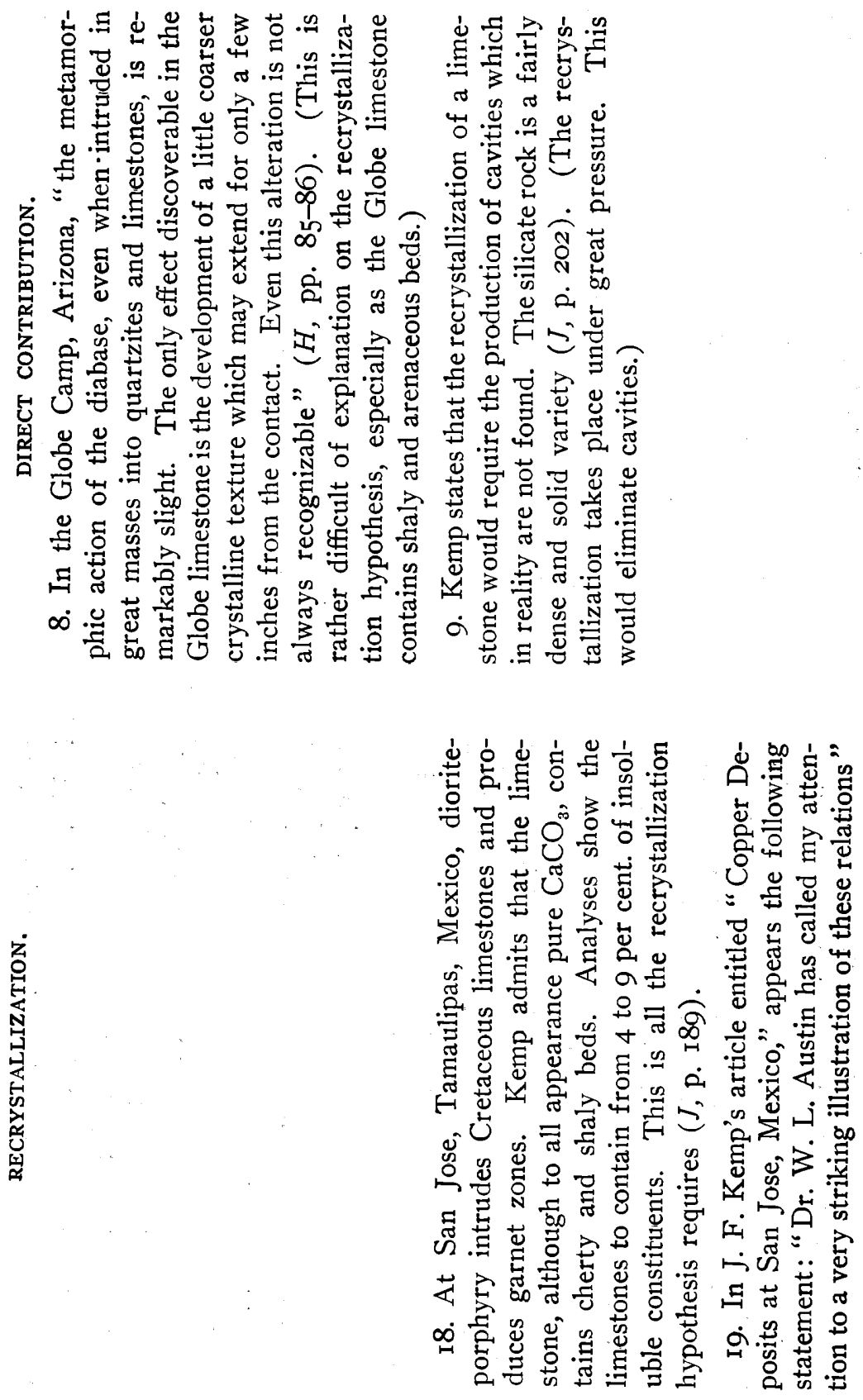


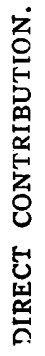

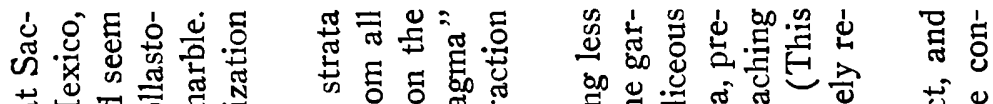

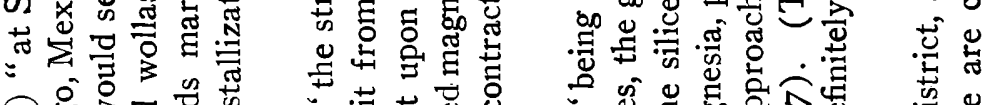

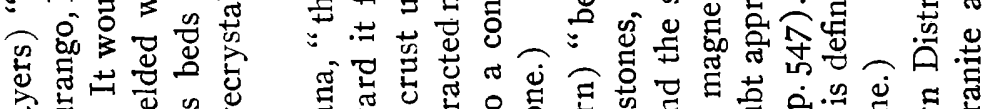

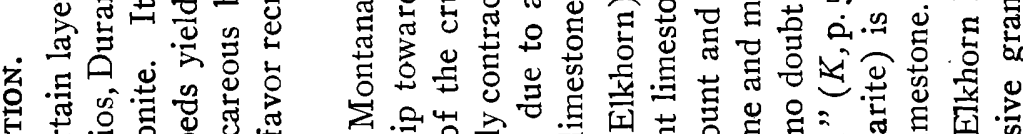

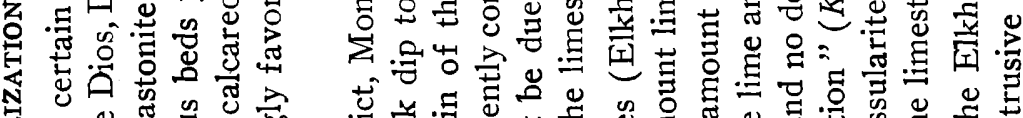

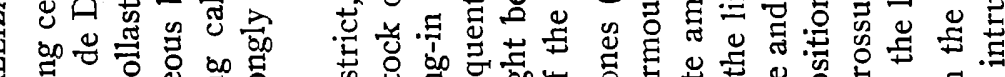
<.

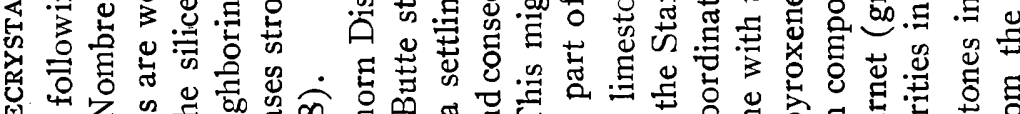

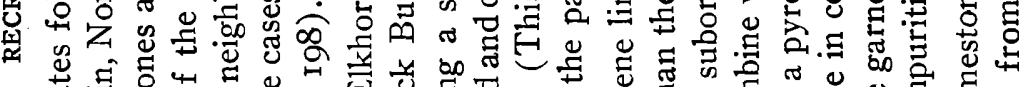

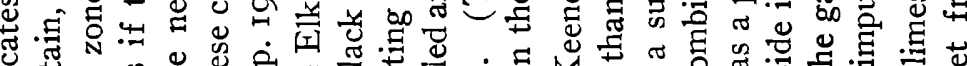

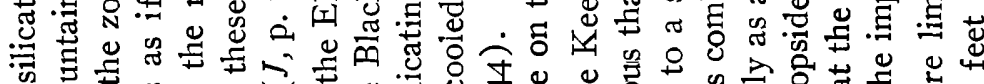

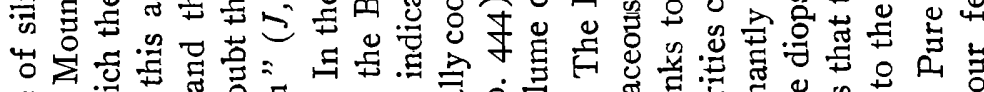

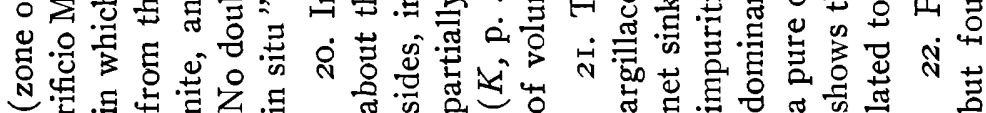


ORIGIN OF SECONDARY SILICATE ZONES.

宫

导寄导焗

ᄋ

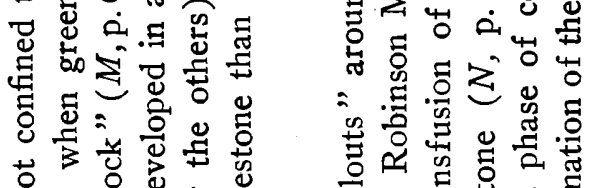

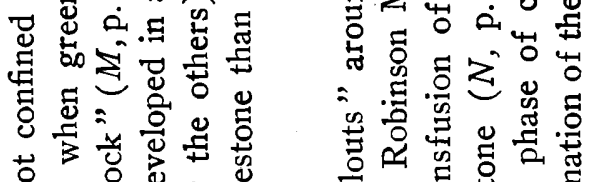

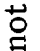

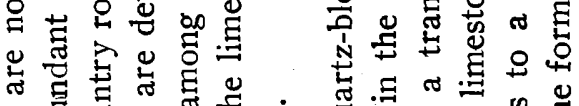

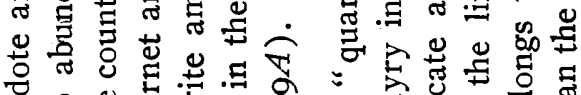

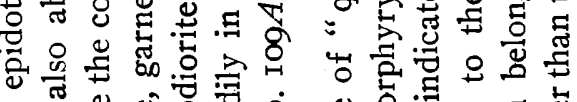

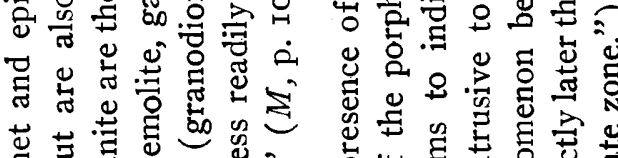

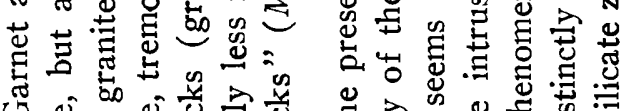

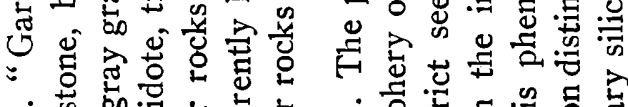

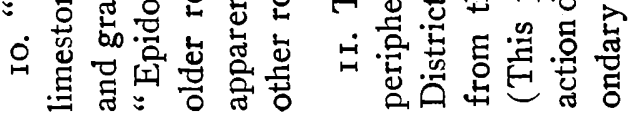

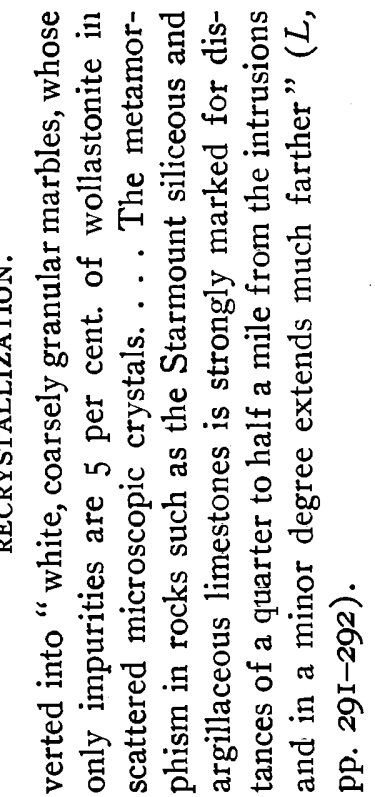

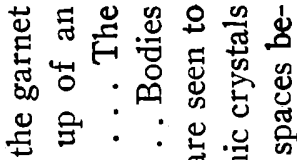

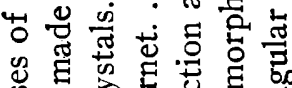

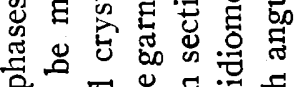

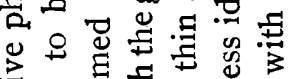

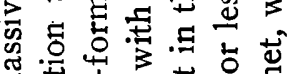

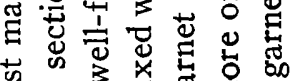

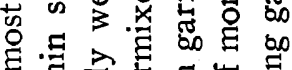

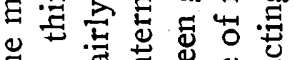

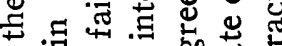

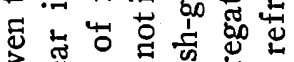

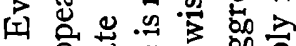

- 空范然 ชं

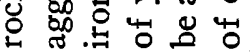




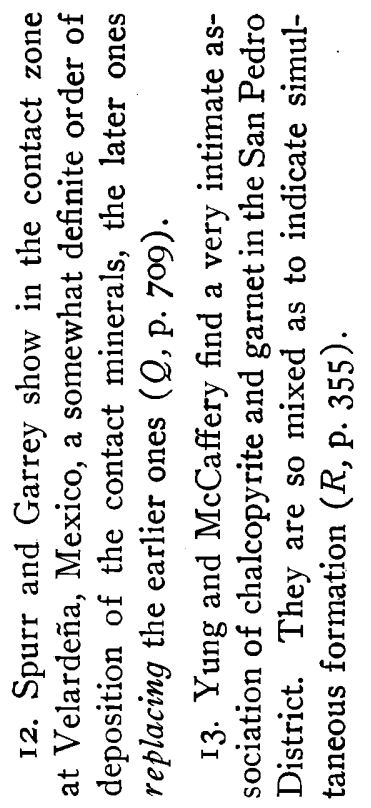

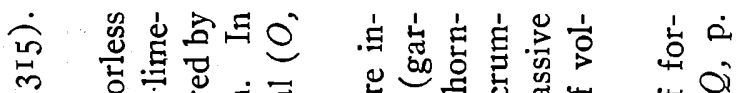

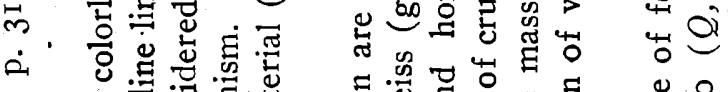

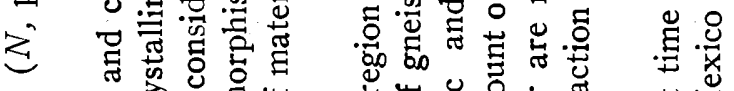

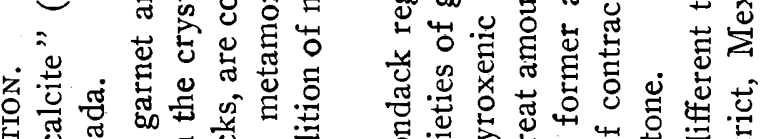

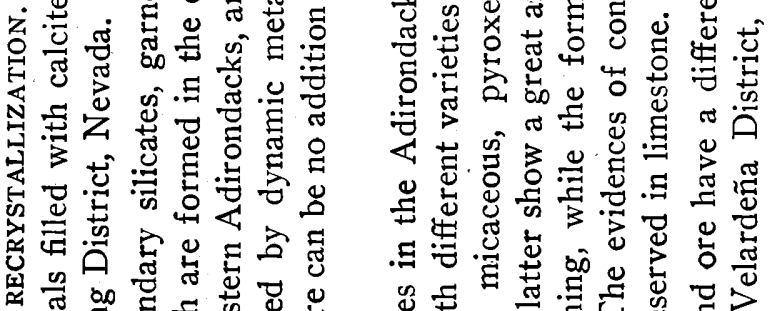

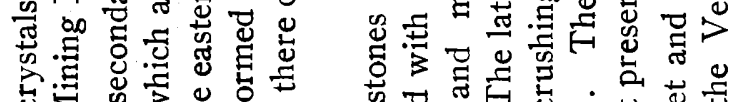

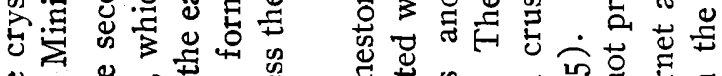

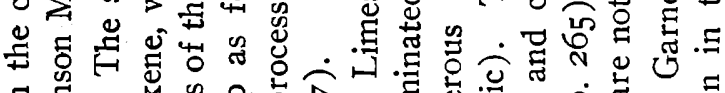

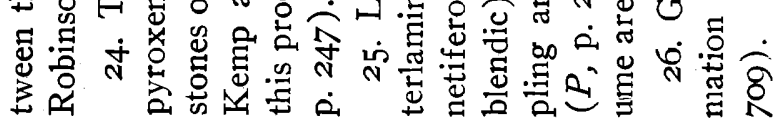



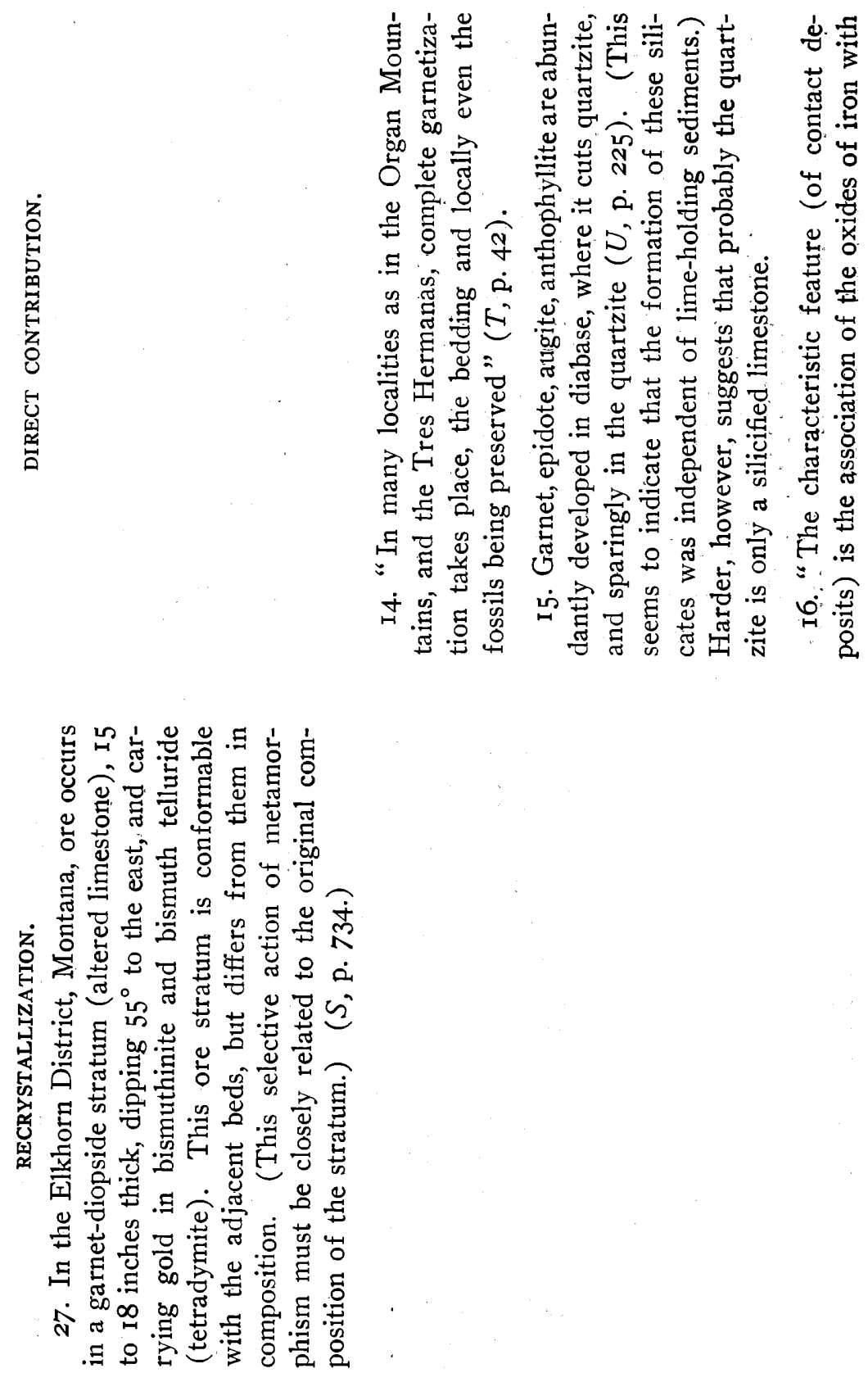


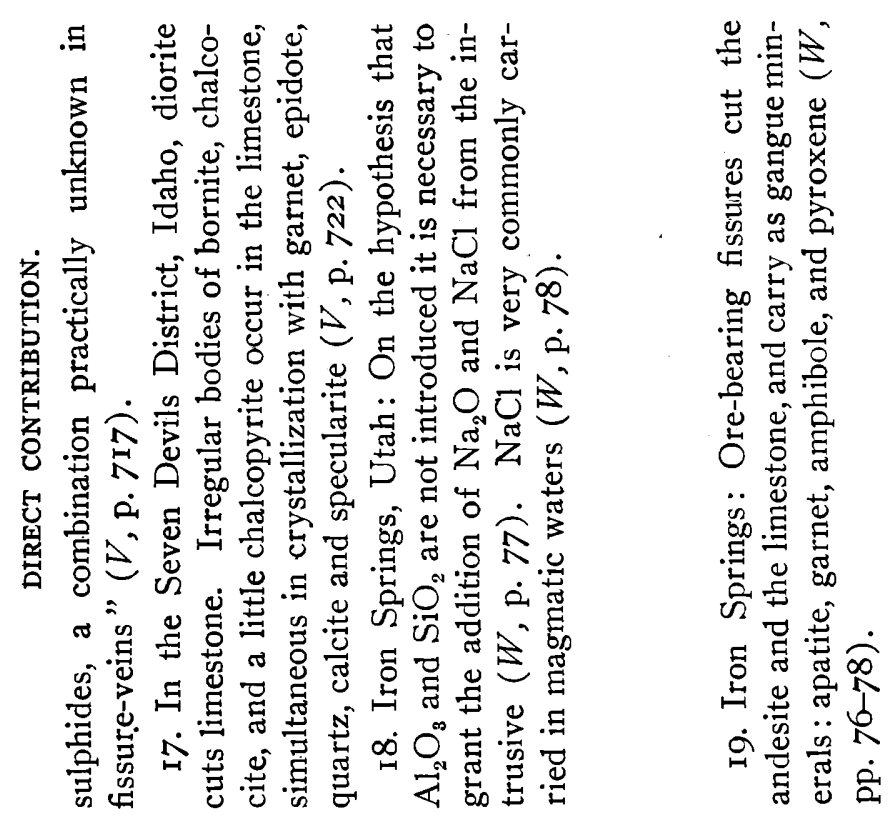

范

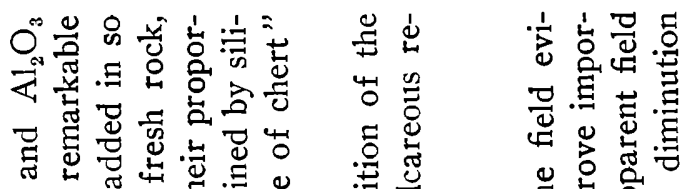

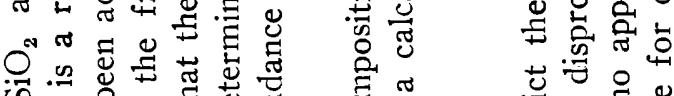

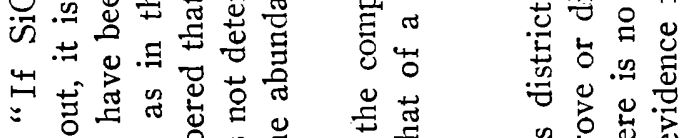

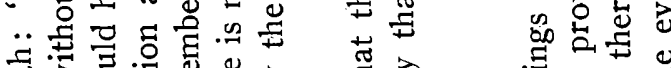

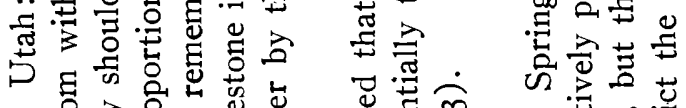

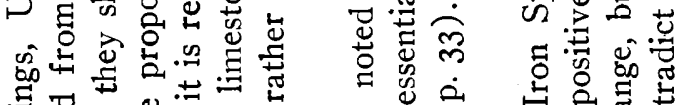

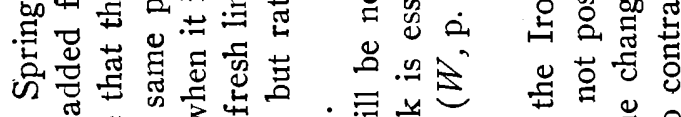

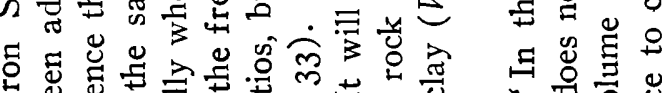

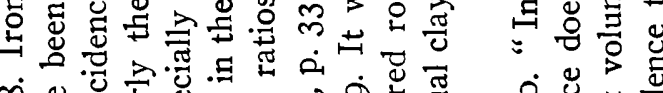

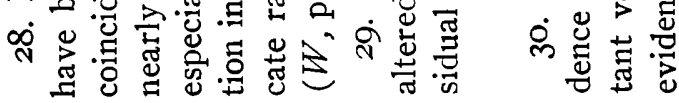


究

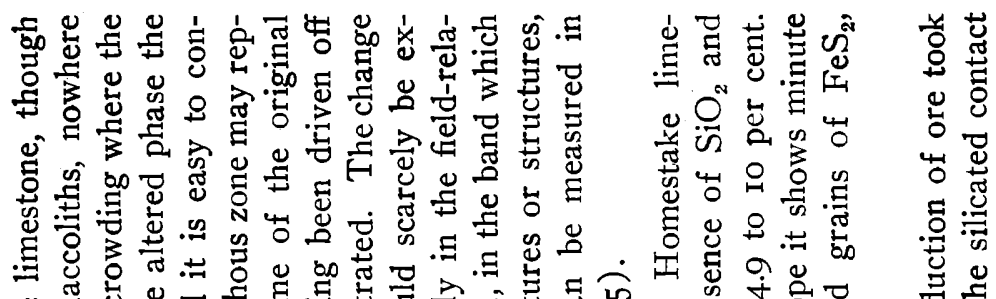

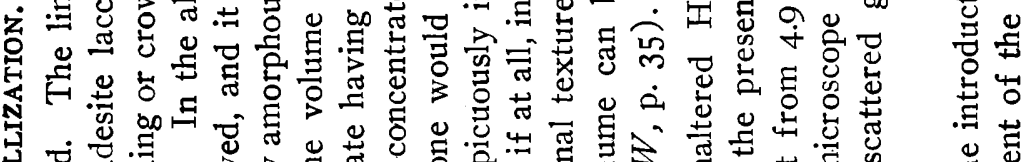

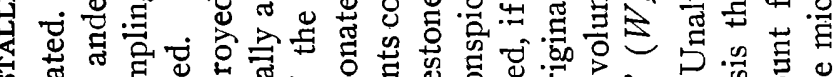

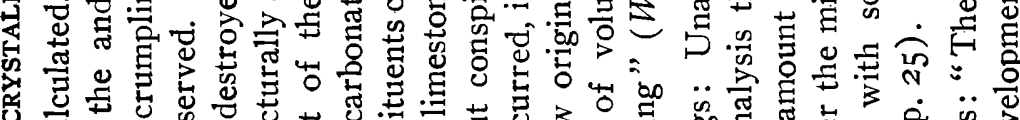

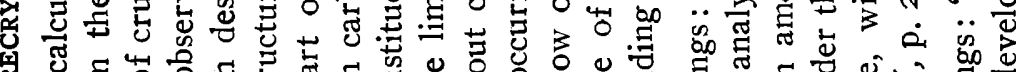

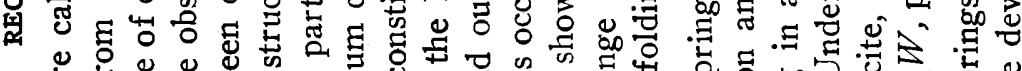

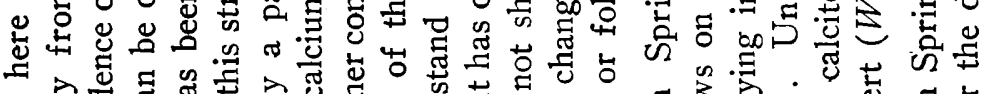

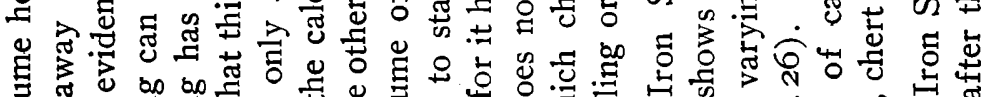

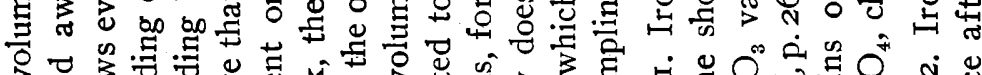

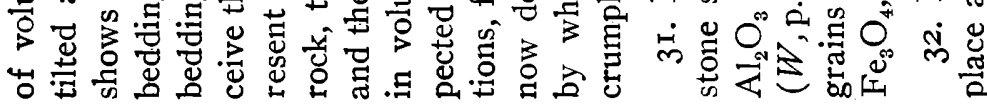




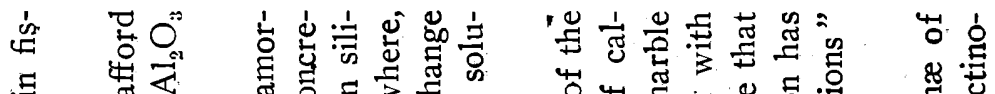

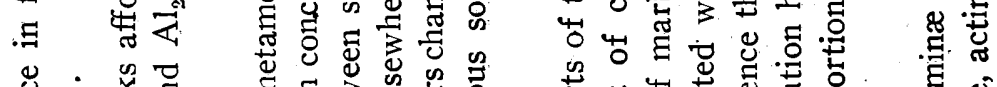

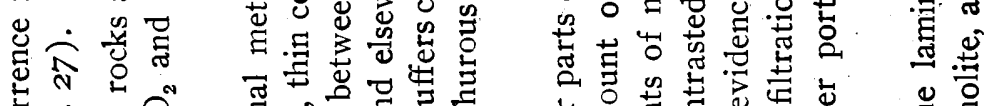

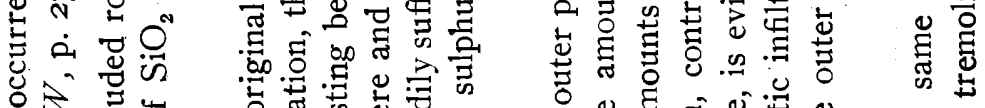

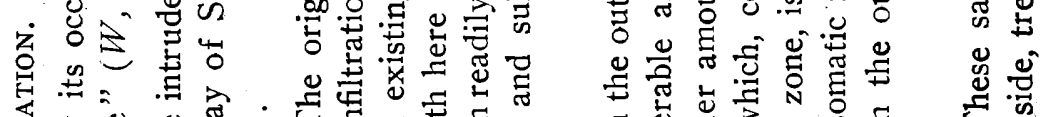

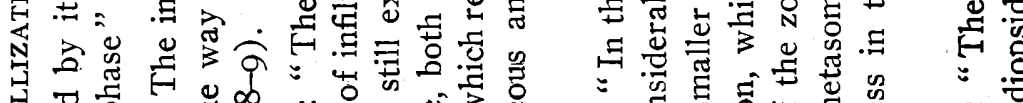

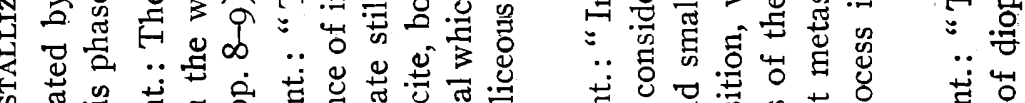

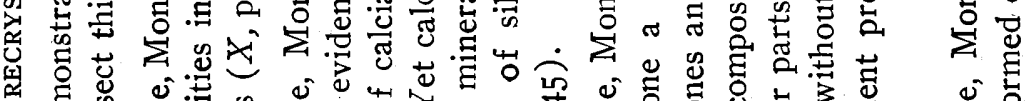

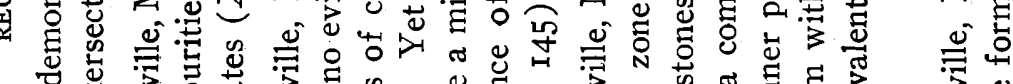

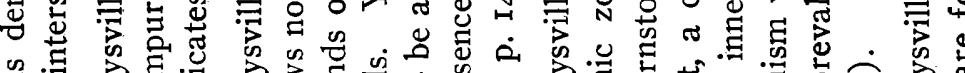
2.

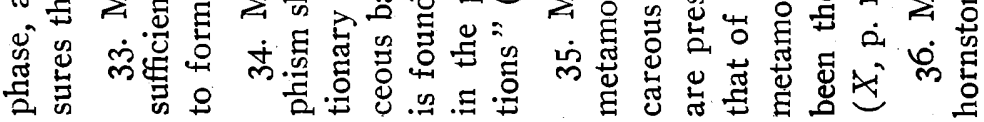


学

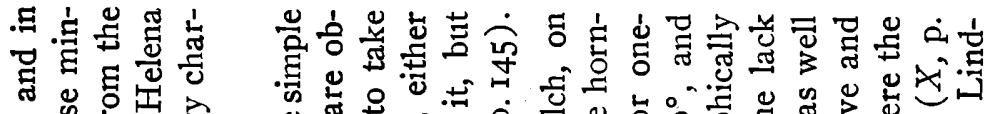

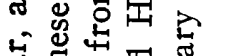
密吉总 过

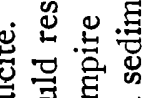

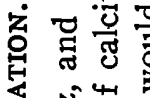

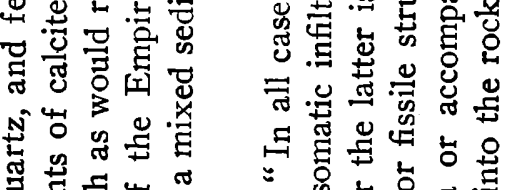
嵌

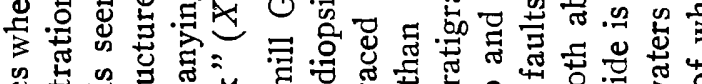

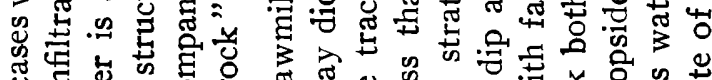

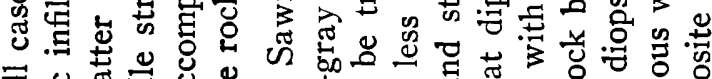

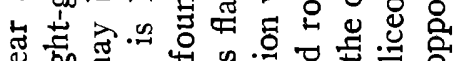

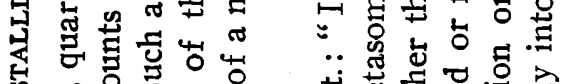
(1)

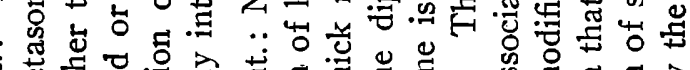

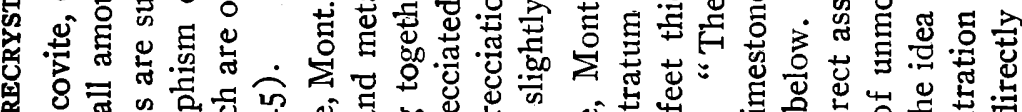

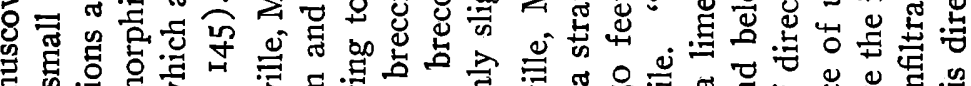

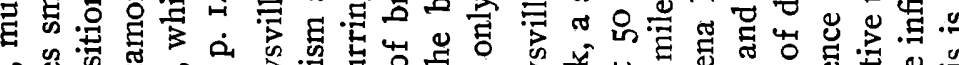

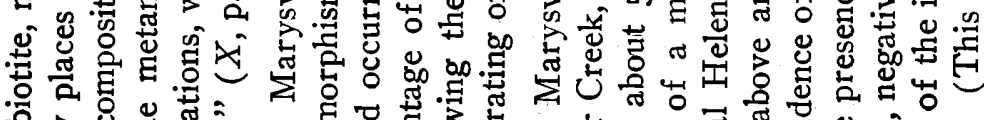

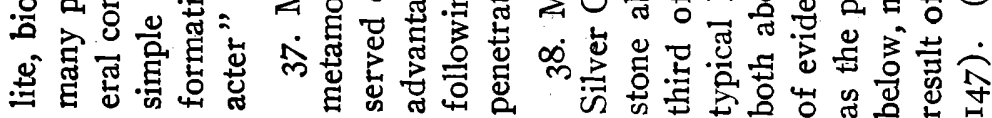




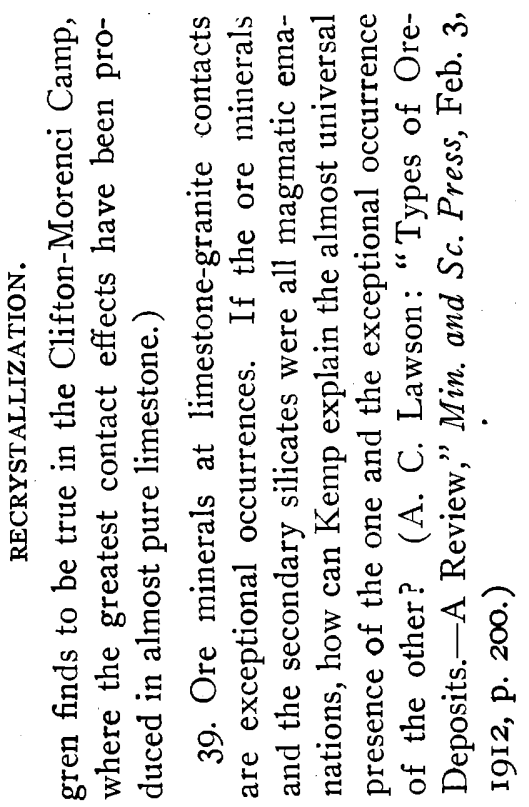


REFERENCES FOR PRECEDING TABLE

A. J. F. Kemp. Contact-Deposits: Types of Ore Deposits. Min. and Sc. Press, I9I I.

B. W. O. Crosby. The Limestone-Granite Contact-Deposits of Washington Camp, Arizona. Trans. A. I. M. E., XXXVI., I905, p. 626.

C. J. F. Kemp and C. G. Gunther: The White Knob Copper Deposits, Mackay, Idaho. Trans. A. I. M. E., XXXVIII., I907, pp. 269-293.

D. F. L. Ransome. U. S. G. S., Prof. Paper 2i (Bisbee).

E. W. Lindgren. U. S. G. S., Prof. Paper 43 (Clifton-Morenci).

$F$. George Smith. The Garnet-Formations of the Chillagoe Copper Field, North Queensland, Australia. Trans. A. I. M. E., XXXIV., I904, p. 467.

G. W. P. Blake. Copper-Ore and Garnet in Association. Trans. A. I. M. E., XXXIV., I904, p. 886.

H. F. L. Ransome. U. S. G. S., Prof. Paper I2 (Globe, Ariz.).

$J$. J. F. Keмp. The Copper-Deposits at San Jose, Tamaulipas, Mexico. Trans. A. I. M. E., XXXVI., I905, p. I78.

$K$. W. H. Weed and J. Barrell. Geology and Ore Deposits of the Elkhorn Mining District, Jefferson County, Montana. U. S. G. S., 22 d Ann. Rept., Part II.

L. J. Barrell. Physical Effects of Contact Metamorphism. Am. Jour. Sc., I902, p. 279.

M. R. W. Brock. Boundary Creek District, B. C. Summary Reports, Can. Geol. Survey, I90I, p. 51 ; I902, p. 92.

$N$. A. C. Lawson. The Copper Deposits of the Robinson Mining District, Nevada. Univ. Cal., Dept. Geol., Bull., Vol. IV., I906, p. 287 .

O. J. F. Kemp. Rocks of the Eastern Adirondacks. Bull. Geol. Soc. Am., Vol. VI., I894, p. 24I.

P. C. H. Sмyтн, Jr. Rocks of the Northwestern Adirondack Region. Bull. Geol. Soc. Am., Vol. VI., I894, p. 263.

Q. J. E. Spurr and G. H. Garrey. The Copper Deposits of the Velardeña District, Durango, Mexico. Econ. Geol., Vol. III., p. 688.

$R$. M. B. Yung and R. S. McCaffery. The Ore Deposits of the San Pedro District, New Mexico. Trans. A. I. M. E., Vol. XXXIII., 1903, P. 350.

S. W. H. WeEd. Ore Deposits near Igneous Contacts. Trans. A. I. M. E., Vol. XXXIII., I903, p. 7I5.

T. W. Lindgren, L. C. Graton and C. H. Gordon. The Ore Deposits of New Mexico. U. S. G. S., Prof. Paper 68, r9io.

$U$. E. C. Harder. The Iron Ores of Western and Central California. U. S. G. S., Bull. 430, 1909, p. 219. 
V. W. Lindgren. The Character and Genesis of Certain ContactDeposits; Genesis of Ore-Deposits, p. 716.

$W$. C. K. Letth and E. C. Harder. The Iron Ores of the Iron Springs District, Utah. U. S. G. S., Bull. 338.

$X$. J. Barrell. Geology of the Marysville Mining District, Montana. U. S. G. S., Prof. Paper 57, 1907.

\section{SUMMARY OF CRITERIA.}

In the following summary is a tabulation of the chief points favoring one or other of the two hypotheses discussed above. The lists are arranged without reference to the special districts from which the various pieces of evidence are taken. A few suggestions are also offered which are in line with the hypothesis of recrystallization. It must be remembered that the use of the term "secondary silicate zone" is in accordance with the interpretation given on page 14 .

$A$. CRITERIa WHich Favor the formation of the "SECONDARY SILICATE ZONES” BY RECRYSTALLIZATION

OF IMPURE LIMESTONES.

I. In every case examined, where detailed descriptions of the intruded strata were given, it was noted that there was a plentiful supply of $\mathrm{SiO}_{2}, \mathrm{Al}_{2} \mathrm{O}_{3}, \mathrm{Fe}_{2} \mathrm{O}_{3}$, scattered through the rock in the way of quartz, kaolin, and limonite, hematite or pyrite, to afford materials for the formation of the silicates.

2. The natural recrystallizations of impure sediments are almost exactly those that are found at intrusive contacts: Sandstones are altered to quartzites. Shales are altered to epidoteamphibole rocks. Limestones (dolomitic) are altered to iron,garnet and diopside.

3. $\mathrm{Al}_{2} \mathrm{O}_{3}$ is practically unknown in igneous emanations.

4. The composite straight-line diagram described in the succeeding section shows a constancy of the $\mathrm{SiO}_{2}: \mathrm{Al}_{2} \mathrm{O}_{3}: \mathrm{Fe}\left(\mathrm{Fe}_{2} \mathrm{O}_{3}\right)$ ratio throughout the change from fresh to altered rock.

5. The composition of an average sample of the rock from the "contact zone" is practically that of a calcareous residual clay (that is, a limestone after the $\mathrm{CaCO}_{3}$ has been dissolved and carried away). 
6. The garnet zones, as described by several of the writers, seem to follow the impure beds in the sediments, independently of the contact.

7. If the silicates were formed by infiltration of material, it would seem a very peculiar feature that just those oxides should be added which are almost invariably present as impurities in any limestone horizon.

8. It would also be exceeedingly peculiar that these oxides should be added in the same ratio as that in which they are to be found in the unaltered limestone series.

9. Masses of marble against the intrusive seem capable of explanation only on the recrystallization hypothesis. It is difficult to conceive of hot siliceous vapors being emitted at the contact with one bed and not with another.

ro. There is no reason why the garnet zones should fail, as they do very often, just where $\mathrm{SiO}_{2}$ and $\mathrm{Al}_{2} \mathrm{O}_{3}$ are wanting in the limestone.

II. Selective metamorphism on a large scale is a prominent feature of these limestone contacts (see page 30, No. 27).

I2. Wherever the garnet masses were examined in thin section under the microscope, it was found that the garnet was present in well-defined crystals, many of them idiomorphic with residuary calcite frequently occupying the interstices. In some cases, the crystals showed double refraction probably due to strain. It seems more probable that these crystals should form by a process of recrystallization after elimination of excess constituents, than by pure replacement (in which the structure and texture of the replaced rock are usually preserved) or by infiltration.

I3. The reaction-zones of wollastonite, occurring between nodules of chert and the limestone, found by Crosby in the Washington camp, Arizona, are conclusive proof of the formation of at least some of the silicates by recrystallization without infiltration.

14. Lindgren's failure to find fluid inclusions in the quartz grains of the contact zone, although he found them abundantly in 
the quartz of the intrusives, is evidence that at least a different origin must be found for the quartz of the contact zone, from that of the quartz of the igneous rocks.

I5. The presence of residuary calcite in the interstices of the garnet crystals is difficult of explanation on the hypothesis of infiltration. If $\mathrm{SiO}_{2}$ was introduced in gaseous or aqueous form, why did it not unite with this lime, that often occurs very close to the contact, rather than pass it by to seek other lime at a greater distance?

I6. Recrystallization into marble and silicates obliterates evidences of volume change. Hence the fact that signs of reduction of volume cannot usually be seen does not argue against recrystallization.

I7. A comparison of the "secondary silicate zones" around intrusives with the talcose and serpentinous material formed by shearing in the Randville dolomite of the Menominee region ${ }^{1}$ is interesting. In the latter case, there has been an elimination of $\mathrm{CaCO}_{3}$, and a recrystallization under great heat and pressure, in the absence of igneous rocks, of dolomitic limestone to silicates. This is almost exactly the same result as occurs at limestone contacts with intrusives.

I8. In all cases of contact metamorphism of limestones the substances apparently added by the intrusive are silica, alumina, and iron oxide. The metallic and other constituents which are * of undoubted magmatic origin vary widely in character and quantity. Sometimes there is iron, sometimes copper, often both. Again there is gold, silver, manganese. Nickel, titanium, beryllium, boron, fluorine, molybdenum, tin, tungsten, tellurium, etc., occur frequently. It seems rather unusual that the typical pneumatolytic constituents should vary so widely from place to place, while the constituents that go to form the "contact-silicates" should be so uniform, if they are all supposed to have the same origin.

19. In most cases, evidence is sufficient to show that without much doubt, there are two stages in the formation of the lime-

${ }^{1}$ U. S. G. S., Mon. 46, p. 221. 
stone contact-zones. This favors the recrystallization rather than the infiltration hypothesis.

20. Advocates of the infiltration theory argue that it is preposterous to demand the reduction of volume required according to the recrystallization hypothesis. On the other hand it is just as improbable that there has been an introduction of such a tremendous amount of material from the intrusive, as is required by those who believe in infiltration.

21. In accordance with the theory of crystallization of a magma the volatile constituents and mineralizers are emitted chiefly while the magma is changing from the liquid to the solid form. If a magma be intruded into a series of impure limestones, at a temperature of $\mathrm{I}, \mathrm{OOO}^{\circ}$, for instance, is it not likely that great changes will take place in the composition of the invaded rock, while the intrusive is cooling down to the temperature of crystallization? As a matter of fact, it is a very common occurrence to find pegmatite dikes, aplite dikes, quartz veins ("blouts" of Lawson) cutting across the already formed "contact zone" of silicates. In these dikes and veins, the mineralizers of the intrusive are very largely concentrated.

22. The katamorphism of limestones in the southern Appalachians gives a residual clayey material, but is used as iron ore. The percentages of $\mathrm{SiO}_{2}, \mathrm{Al}_{2} \mathrm{O}_{3}, \mathrm{Fe}$ in the fresh limestone are in the same ratio as in the ore material. ${ }^{1}$ If anamorphosed, these deposits would give secondary silicates with free iron oxide.

B. CRITERIA WHICH FAVOR THE FORMATION OF THE "SECONDARY SILICATE ZONES" BY INFILTRATION OF MATERIAL.

I. In many cases, garnet masses are found entirely apart from limestones, and apparently connected entirely with intrusive igneous rocks.

2. As a general rule, the literature bears out the statement that basic intrusives do not produce nearly as great a contact zone as acidic ones. Acidic magmas or those high in silica are

${ }^{1}$ R. J. Holden, "The Brown Ores of the New River, Cripple Creek District, Va.," U. S. G. S., Bull. 285. 
the rocks generally believed to be most richly provided with the so-called mineralizers. ${ }^{1}$ It is an interesting coincidence that cold, basic rocks have been found by Rollin Chamberlin ${ }^{2}$ to be the richest in gases.

3. The garnet of the contact zones is in the majority of cases the andradite (calcium-iron) variety. This demands a large amount of iron oxide.

4. A very intimate mixture of chalcopyrite with the silicates in some camps indicates a simultaneous crystallization.

5. In many localities in New Mexico, the bedding and locally the fossils are preserved in garnet.

${ }^{1}$ J. F. Kemp, "Contact Deposits"; see "Types of Ore Deposits," H. F. Bain.

${ }^{2}$ R. Chamberlin, "Gases in Rocks," Publication 106, Carnegie Institute of Washington, I908. 